A $\underset{\text { publications }}{\mathrm{C}} \quad$ Rec. Nat. Prod. 15:1 (2021) 59-64

\title{
Chemical Constituents of Gymnosporia stylosa and Their Anti-inflammatory Activities
}

\section{Dang Thach Tran $\odot^{1, \dagger}$, Phi Hung Nguyen $\odot^{2,3, \dagger}$, Manh Hung Tran $\odot^{4}$, Phuong Dai Nguyen Nguyen $\oplus^{5}$, Truong Nhan Ngu@ 5 , Thi Huyen Thoa Pham $\oplus^{5}$ and Dao Cuong To $\oplus^{6,7, *}$}

\author{
${ }^{1}$ Industrial University of Vinh, 26 Nguyen Thai Hoc, Doi Cung, Vinh city, Nghe An, Vietnam \\ ${ }^{2}$ Institute of Natural Products Chemistry, Vietnam Academy of Science and Technology (VAST), 18 \\ Hoang Quoc Viet, Cau Giay, Hanoi, Vietnam \\ ${ }^{3}$ Graduate University of Science and Technology, VAST, 18 Hoang Quoc Viet, Cau Giay, \\ Hanoi 122100, Vietnam \\ ${ }^{4}$ Biomedical Sciences Department, VNUK Institute for Research and Executive Education, \\ The University of Danang, 158A Le Loi street, Hai Chau district, Da Nang 551000, Vietnam \\ ${ }^{5}$ Faculty of Natural Science and Technology, Tay Nguyen University, 567 Le Duan, Ea Tam, \\ Buon Ma Thuot City 630000, Vietnam \\ ${ }^{6}$ Faculty of Pharmacy, Phenikaa University, Yen Nghia, Ha Dong district, Hanoi 12116, Vietnam \\ ${ }^{7}$ Phenikaa Research and Technology Institute (PRATI), A\&A Green Phoenix Group JSC, 167 Hoang \\ Ngan, Cau Giay district, Hanoi 11313, Vietnam
}

(Received March 10, 2020; Revised April 21, 2020; Accepted April 26, 2020)

\begin{abstract}
A new flavanone glycoside, gymnosporioside (1), and three known compounds (2-4) were isolated from the leaves of Gymnosporia stylosa. The structure of gymnosporioside (1) was determined by nuclear magnetic resonance (NMR), time-of-flight mass spectrometry (TOFMS), and circular dichroism (CD) spectral data. The known compounds were identified as prunin (2), acteoside (3), and isoacteoside (4), by comparing the NMR data from this study with those reported in the literature. These known compounds, $\mathbf{2}-\mathbf{4}$, have not been previously isolated from $G$. stylosa. Their anti-inflammatory activities were evaluated against lipopolysaccharides (LPS)-induced activation of nitric oxide (NO) production in RAW264.7 cells, in vitro. Compounds 3 and $\mathbf{4}$ showed significant inhibitory activities against LPS-induced NO production in RAW264.7 cells, with $\mathrm{IC}_{50}$ values of $17.8 \pm 0.4$ and $19.3 \pm 0.3 \mu \mathrm{M}$, respectively.
\end{abstract}

Keywords: Gymnosporia stylosa; Celastraceae; flavanone; anti-inflammatory. (C) 2020 ACG Publications. All rights reserved.

\section{Plant Source}

The leaves of Gymnosporia stylosa was collected in Thua Thien Hue province, Vietnam, and authenticated by Dr. Nguyen Quoc Binh, Vietnam National Museum of Nature, VAST. A voucher specimen (VN1844) has been stored at Institute of Natural Products Chemistry, VAST.

\footnotetext{
† These authors contributed equally to this work.

* Corresponding author: E-mail: cuong.todao@phenikaa-uni.edu.vn (D. C. To), Phone +84-971-886989
} 


\section{Previous Studies}

G. stylosa is a member of the Gymnosporia genus, which is one of the largest genera in the Celastraceae family. This family consists of approximately 100 genera and 1,300 species, which are primarily distributed in tropical regions [1]. Gymnosporia species are rich in triterpenoid, sesquiterpenoid, alkaloid, flavonoid, and phenolic compounds [2]. Gymnosporia species have also been found to possess biological activities, including antioxidative [3], hepatoprotective [4], cytotoxic [5], antimicrobial [6], and anti-inflammatory activities [7]. G. stylosa has been recognized as an oriental medicinal plant, with cytotoxic activity [2]. Previous studies examining the chemical constituents in G. stylosa have identified the presence of triterpenoid and phenolic compounds [2].

\section{Present Study}

Dried, powdered G. stylosa leaves $(2 \mathrm{~kg})$ were extracted using $\mathrm{MeOH}(3 \times 8 \mathrm{~L})$, by refluxing, to produce $165 \mathrm{~g}$ crude extract. The crude extract was suspended in water $(800 \mathrm{~mL})$ and successively partitioned, using $\mathrm{CHCl}_{3}(4 \times 1 \mathrm{~L})$ and EtOAc $(4 \times 1 \mathrm{~L})$. The EtOAc extract $(65.0 \mathrm{~g})$ was applied to an open silica gel column chromatography (CC) and eluted with $\mathrm{CHCl}_{3}-\mathrm{MeOH}$ (10:1 to 0:1), yielding eighteen fractions (E1-E18). Fraction E11 (5.2 g) was further subjected to silica gel CC and eluted with $\mathrm{CHCl}_{3}-\mathrm{EtOAc}-\mathrm{MeOH}$ (5:1:0 to 0:1:1), yielding ten sub-fractions (E11.1-E11.10). Further purification of the sub-fraction E11.5 (510 mg), using an Agilent 1260 HPLC, Optima Pak RP-C18 column ( $10 \times 250 \mathrm{~mm}$ ID, $5 \mu \mathrm{M}$ particle size) and $\mathrm{MeOH}-\mathrm{H}_{2} \mathrm{O}+0.1 \%$ formic acid $(25: 75 \rightarrow 35: 65)$ as the eluent, resulted in the isolation of compounds $1(12.5 \mathrm{mg})$ and $\mathbf{2}(16.7 \mathrm{mg})$. Fraction E17 $(1.8 \mathrm{~g})$ was also subjected to silica gel CC, eluted with $\mathrm{CHCl}_{3}-\mathrm{MeOH}(5: 1$ to $0: 1)$, yielding five sub-fractions (E17.1 - E17.5). Further purification of sub-fraction E17.3 (325 mg), using an Agilent 1260 HPLC, Optima Pak RP-C18 column ( 10 x $250 \mathrm{~mm}$ ID, $5 \mu \mathrm{M}$ particle size) and $\mathrm{MeOH}-\mathrm{H}_{2} \mathrm{O}+0.1 \%$ formic acid (15:85 $\rightarrow 30: 70)$ as the eluent, resulted in the isolation of compounds 3 (20.8 mg) and 4 (15.5 $\mathrm{mg})$.

Determination of NO Production. The level of NO production was determined by measuring the amount of nitrite present in cell culture supernatants as described previously [8-10].

Compound 1: Yellow amorphous powder; $[\alpha]_{\mathrm{D}}^{25}-112.4^{\circ}(c 0.2, \mathrm{MeOH}) ; \mathrm{UV} \lambda_{\max }(\mathrm{MeOH}): 282,332$ $\mathrm{nm}$; IR $(\mathrm{KBr}) v_{\max } 3400(\mathrm{OH}), 2858,1710,1628(\mathrm{C}=\mathrm{O}), 1588,1518 \mathrm{~cm}^{-1}$; TOFMS $\mathrm{m} / z 647.1717$ [M $+\mathrm{Na}]^{+}\left(\mathrm{Calcd}\right.$ for $\left.\mathrm{C}_{32} \mathrm{H}_{32} \mathrm{O}_{13} \mathrm{Na}, 647.1735\right) ; \mathrm{CD}(c 0.01, \mathrm{MeOH}): \Delta \varepsilon_{277}-16.55, \Delta \varepsilon_{303}+8.75 ;{ }^{1} \mathrm{H} \mathrm{NMR}$ $\left(400 \mathrm{MHz}\right.$, Methanol- $\left.d_{4}\right) \delta_{\mathrm{H}}(\mathrm{ppm}): 5.44(1 \mathrm{H}, \mathrm{dd}, J=2.8,13.2 \mathrm{~Hz}, \mathrm{H}-2), 2.74(1 \mathrm{H}, \mathrm{dd}, J=13.2,16.8$ $\left.\mathrm{Hz}, \mathrm{H}-3_{a x}\right), 2.88\left(1 \mathrm{H}, \mathrm{dd}, J=2.8,16.8 \mathrm{~Hz}, \mathrm{H}-3_{e q}\right), 5.90(1 \mathrm{H}, \mathrm{s}, \mathrm{H}-6), 7.28\left(1 \mathrm{H}, \mathrm{d}, J=8.8 \mathrm{~Hz}, \mathrm{H}-3^{\prime}\right)$, $6.75\left(1 \mathrm{H}, \mathrm{dd}, J=2.8,8.8, \mathrm{H}-4^{\prime}\right), 7.07\left(1 \mathrm{H}, \mathrm{d}, J=2.8 \mathrm{~Hz}, \mathrm{H}-6^{\prime}\right), 4.93\left(1 \mathrm{H}, \mathrm{d}, J=8.0 \mathrm{~Hz}, \mathrm{H}-1^{\prime \prime}\right), 5.12$ $\left(1 \mathrm{H}, \mathrm{dd}, J=8.0,9.6 \mathrm{~Hz}, \mathrm{H}-2^{\prime \prime}\right), 3.68\left(1 \mathrm{H}, \mathrm{m}, \mathrm{H}-3^{\prime \prime}\right), 3.49\left(1 \mathrm{H}, \mathrm{m}, \mathrm{H}-4^{\prime \prime}\right), 3.51\left(1 \mathrm{H}, \mathrm{m}, \mathrm{H}-5^{\prime \prime}\right), 4.01$ $\left(1 \mathrm{H}, \mathrm{br} \mathrm{d}, J=12.0 \mathrm{~Hz}, \mathrm{H}-6^{\prime \prime} \mathrm{a}\right), 3.79$ (1H, dd, $\left.J=5.2,12.0 \mathrm{~Hz}, \mathrm{H}-6^{\prime \prime} \mathrm{b}\right), 7.36$ (2H, m, H-2'"'/H-6"' $)$, 7.34 (2H, m, H-3"'//H-5'"'), 7.39 (1H, m, H-4"') $7.42\left(1 \mathrm{H}, \mathrm{d}, J=16.0 \mathrm{~Hz}, \mathrm{H}-7^{\prime \prime \prime}\right), 6.37$ (1H, d, $J=16.0$ $\left.\mathrm{Hz}, \mathrm{H}-8^{\prime \prime \prime}\right), 3.70\left(3 \mathrm{H}, \mathrm{s}, 7-\mathrm{OC}_{3}\right), 3.47\left(3 \mathrm{H}, \mathrm{s}, 8-\mathrm{OCH}_{3}\right) ;{ }^{13} \mathrm{C}$ NMR $\left(100 \mathrm{MHz}\right.$, Methanol- $\left.d_{4}\right) \delta_{\mathrm{C}}(\mathrm{ppm})$ : 75.8 (C-2), 43.5 (C-3), 198.0 (C-4), 103.8 (C-4a), 160.8 (C-5), 94.2 (C-6), 162.4 (C-7), 130.6 (C-8), 154.8 (C-8a), $131.2\left(\mathrm{C}-1^{\prime}\right), 148.3\left(\mathrm{C}-2^{\prime}\right), 119.1\left(\mathrm{C}-3^{\prime}\right), 116.5\left(\mathrm{C}-4^{\prime}\right), 154.6\left(\mathrm{C}-5^{\prime}\right), 113.2\left(\mathrm{C}-6^{\prime}\right), 102.9$ $\left(\mathrm{C}-1^{\prime \prime}\right), 75.1\left(\mathrm{C}-2^{\prime \prime}\right), 75.7\left(\mathrm{C}-3^{\prime \prime}\right), 71.6\left(\mathrm{C}-4^{\prime \prime}\right), 78.4\left(\mathrm{C}-5^{\prime \prime}\right), 62.5\left(\mathrm{C}-6^{\prime \prime}\right), 135.2\left(\mathrm{C}-1^{\prime \prime \prime}\right), 129.8$ (C-2'"'/C-

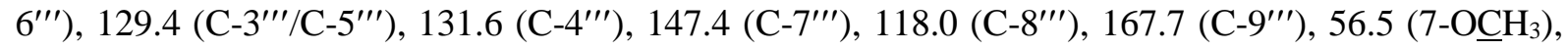
$61.3\left(8-\mathrm{OCH}_{3}\right)$. 


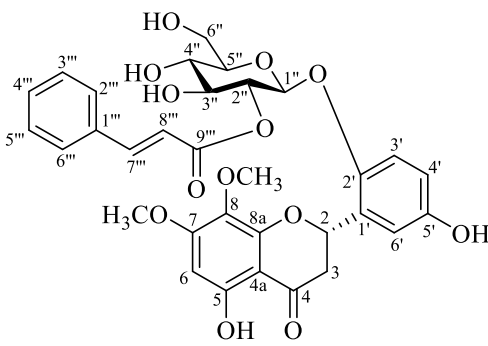

1

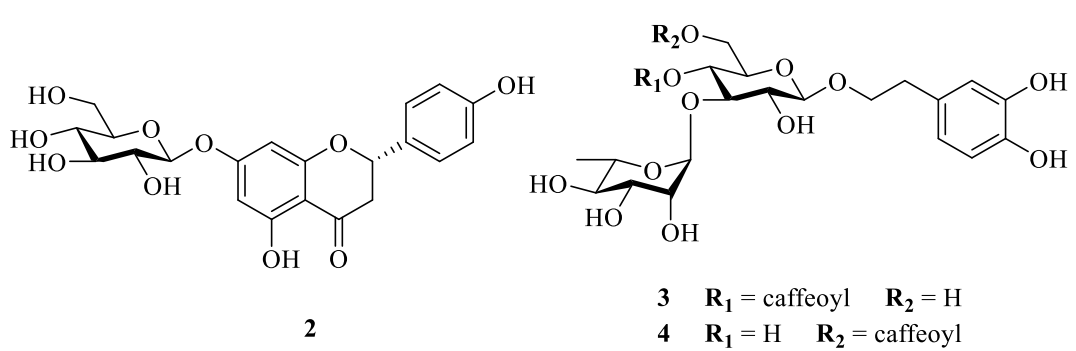

Figure 1. Chemical structure of the compounds (1-4) isolated from $G$. stylosa

Compound 1 was obtained as a yellow, amorphous powder, with an optical rotation of $[\alpha]_{D}^{25}-$ $112.4^{\circ}$. The molecular formula of $\mathbf{1}$ was determined to be $\mathrm{C}_{32} \mathrm{H}_{32} \mathrm{O}_{13}$, based on the molecular ion peak at $\mathrm{m} / z 647.1717$ for the $[\mathrm{M}+\mathrm{Na}]^{+}$ion (calcd. for $\mathrm{C}_{32} \mathrm{H}_{32} \mathrm{O}_{13} \mathrm{Na}, 647.1735$ ) in the TOFMS analysis. The ultraviolet (UV) spectrum displayed maximum absorption bands at 282 and $332 \mathrm{~nm}$. The infrared (IR) spectrum of compound 1 indicated the presence of a hydroxyl group $\left(3400 \mathrm{~cm}^{-1}\right)$, ketone $\left(1710 \mathrm{~cm}^{-1}\right)$, carbonyl carbon $\left(1628 \mathrm{~cm}^{-1}\right)$, and aromatic rings $\left(1588\right.$ and $\left.1518 \mathrm{~cm}^{-1}\right)$. The presence of an oxymethine group $\left[\delta_{\mathrm{H}} 5.44(1 \mathrm{H}, \mathrm{dd}, J=2.8,13.2 \mathrm{~Hz}, \mathrm{H}-2) / \delta_{\mathrm{C}} 75.8(\mathrm{C}-2)\right]$, a methylene group $\left[\delta_{\mathrm{H}} 2.74\right.$ $\left(1 \mathrm{H}, \mathrm{dd}, J=13.2,16.8 \mathrm{~Hz}, \mathrm{H}-3_{a x}\right)$ and $\left.2.88\left(1 \mathrm{H}, \mathrm{dd}, J=2.8,16.8 \mathrm{~Hz}, \mathrm{H}-3_{e q}\right) / \delta_{\mathrm{C}} 43.5(\mathrm{C}-3)\right]$, and a ketone at $\delta_{\mathrm{C}} 198.0(\mathrm{C}-4)$, in the ${ }^{1} \mathrm{H}$ and ${ }^{13} \mathrm{C}$ NMR spectra, indicated that compound 1 was a flavanone (Figure 1 and Supporting information) [11,12]. The ${ }^{1} \mathrm{H}$ NMR spectrum of compound 1 further revealed the presence of an aromatic proton, at $\delta_{\mathrm{H}} 5.90(1 \mathrm{H}, \mathrm{s}, \mathrm{H}-6)$, two methoxy protons $\left[\delta_{\mathrm{H}} 3.70\right.$ $\left(3 \mathrm{H}, \mathrm{s}, 7-\mathrm{OCH}_{3}\right)$ and $\left.3.47\left(3 \mathrm{H}, \mathrm{s}, 8-\mathrm{OCH}_{3}\right)\right]$, a sugar moiety $\left[\delta_{\mathrm{H}} 4.93\left(1 \mathrm{H}, \mathrm{d}, J=8.0 \mathrm{~Hz}, \mathrm{H}-1^{\prime \prime}\right), 5.12\right.$ $\left(1 \mathrm{H}, \mathrm{dd}, J=8.0,9.6 \mathrm{~Hz}, \mathrm{H}-2^{\prime \prime}\right), 3.68\left(1 \mathrm{H}, \mathrm{m}, \mathrm{H}-3^{\prime \prime}\right), 3.49\left(1 \mathrm{H}, \mathrm{m}, \mathrm{H}-4^{\prime \prime}\right), 3.51\left(1 \mathrm{H}, \mathrm{m}, \mathrm{H}-5^{\prime \prime}\right), 4.01$ $\left(1 \mathrm{H}, \mathrm{br} \mathrm{d}, J=12.0 \mathrm{~Hz}, \mathrm{H}-6^{\prime \prime} \mathrm{a}\right)$, and $\left.3.79\left(1 \mathrm{H}, \mathrm{dd}, J=5.2,12.0 \mathrm{~Hz}, \mathrm{H}-6^{\prime \prime} \mathrm{b}\right)\right]$, and three other aromatic protons $\left[\delta_{\mathrm{H}} 7.28\left(1 \mathrm{H}, \mathrm{d}, J=8.8 \mathrm{~Hz}, \mathrm{H}-3^{\prime}\right), 6.75\left(1 \mathrm{H}, \mathrm{dd}, J=2.8,8.8, \mathrm{H}-4^{\prime}\right)\right.$, and $7.07(1 \mathrm{H}, \mathrm{d}, J=2.8$ $\left.\mathrm{Hz}, \mathrm{H}-6^{\prime}\right)$ ], which were characterized as a 1,2,5-trisubstituted benzene ring (Figure 1). The signals of two trans-olefinic protons $\left[\delta_{\mathrm{H}} 7.42\left(1 \mathrm{H}, \mathrm{d}, J=16.0 \mathrm{~Hz}, \mathrm{H}-7^{\prime \prime \prime}\right), 6.37\left(1 \mathrm{H}, \mathrm{d}, J=16.0 \mathrm{~Hz}, \mathrm{H}-8^{\prime \prime \prime}\right)\right]$ and five aromatic protons $\left[\delta_{\mathrm{H}} 7.36\left(2 \mathrm{H}, \mathrm{m}, \mathrm{H}-2^{\prime \prime \prime} / \mathrm{H}-6^{\prime \prime \prime}\right), 7.34\left(2 \mathrm{H}, \mathrm{m}, \mathrm{H}-3^{\prime \prime \prime} / \mathrm{H}-5^{\prime \prime \prime}\right)\right.$, and $7.39(1 \mathrm{H}, \mathrm{m}, \mathrm{H}-$ $\left.4^{\prime \prime \prime}\right)$ ] indicated the presence of a cinnamoyl group (Figure 1 and Supporting information). The ${ }^{13} \mathrm{C}$ NMR and heteronuclear single quantum correlation (HSQC) spectra exhibited thirty-two signals, due to two methoxy carbons, at $\delta_{\mathrm{C}} 56.5$ and $61.3 \mathrm{ppm}$, and twelve $s p^{2}$ carbons, at $\delta_{\mathrm{C}} 94.2-162.4 \mathrm{ppm}$, indicating the presence of two aglycone benzene rings. In addition, the six-carbon signals of the sugar moiety, at $\delta_{\mathrm{C}} 102.9\left(\mathrm{C}-1^{\prime \prime}\right)$ and $\delta_{\mathrm{C}} 62.5-78.4\left(\mathrm{C}-2^{\prime \prime}-\mathrm{C}-6^{\prime \prime}\right)$, and nine carbon signals of the cinnamoyl group $\left[\delta_{\mathrm{C}} 135.2\left(\mathrm{C}-1^{\prime \prime \prime}\right), 129.8\left(\mathrm{C}-2^{\prime \prime \prime} / \mathrm{C}-6^{\prime \prime \prime}\right), 129.4\left(\mathrm{C}-3^{\prime \prime \prime} / \mathrm{C}-5^{\prime \prime \prime}\right), 131.6\left(\mathrm{C}-4^{\prime \prime \prime}\right), 147.4\left(\mathrm{C}-7^{\prime \prime \prime}\right), 118.0\right.$ $\left(\mathrm{C}-8^{\prime \prime \prime}\right)$, and $\left.167.7\left(\mathrm{C}-9^{\prime \prime \prime}\right)\right]$ were also detected in the ${ }^{13} \mathrm{C}$ NMR spectrum (Figure 1 and Supporting information). Acid hydrolysis of compound 1 yielded D-glucose, which was confirmed by gas chromatography (GC) analysis, according to the previously published method [13]. The glucose linkage was determined as $\beta$, based on the $J_{1,2}$ value $(8.0 \mathrm{~Hz})$ for the anomeric proton [14-16]. Crosspeaks between $\mathrm{H}-2$ and $\mathrm{H}-3, \mathrm{H}-3^{\prime}$ and $\mathrm{H}-4^{\prime}, \mathrm{H}-2^{\prime \prime}$ and $\mathrm{H} 1^{\prime \prime} / \mathrm{H}-3^{\prime \prime}$, and $\mathrm{H}-7^{\prime \prime \prime}$ and $\mathrm{H}-8^{\prime \prime \prime}$ were observed in the correlation spectroscopy (COSY) spectrum (Figure 2 and Supporting information). In the heteronuclear multiple bond correlation (HMBC) spectrum, the oxygenated methine proton at $\delta_{\mathrm{H}} 5.44$ $(\mathrm{H}-2)$ demonstrated long-range correlations with carbon signals at $\delta_{\mathrm{C}} 198.0(\mathrm{C}-4), 154.8(\mathrm{C}-8 \mathrm{a}), 131.2$ $\left(\mathrm{C}-1^{\prime}\right), 148.3\left(\mathrm{C}-2^{\prime}\right)$, and $113.2\left(\mathrm{C}-6^{\prime}\right)$; the aromatic proton at $\delta_{\mathrm{H}} 5.90(\mathrm{H}-6)$ was correlated with carbons at $\delta_{\mathrm{C}} 160.8(\mathrm{C}-5), 162.4(\mathrm{C}-7)$, and $130.6(\mathrm{C}-8)$, as well as two methoxy proton signals $\left(\delta_{\mathrm{H}}\right.$ 3.70 and 3.47), which showed correlations with carbon resonances, at $\delta_{\mathrm{C}} 162.4(\mathrm{C}-7)$ and $130.6(\mathrm{C}-8)$, respectively, indicating the presence of two methoxy groups at C-7 and C-8 (Figure 2 and Supporting information). The anomeric proton at $\delta_{\mathrm{H}} 4.93\left(\mathrm{H}-1^{\prime \prime}\right)$ showed long-range correlation with the carbon signal at $\delta_{\mathrm{C}} 148.3\left(\mathrm{C}-2^{\prime}\right)$, in the HMBC spectrum, suggested that the sugar moiety was located at C-2' 
(Figure 2). Interestingly, the HMBC correlations of the protons at $\delta_{\mathrm{H}} 7.42\left(\mathrm{H}-7^{\prime \prime \prime}\right), \delta_{\mathrm{H}} 6.37\left(\mathrm{H}-8^{\prime \prime \prime}\right)$, and $\delta_{\mathrm{H}} 5.12\left(\mathrm{H}-2^{\prime \prime}\right)$ with the carbon signal at $\delta_{\mathrm{C}} 167.7\left(\mathrm{C}-9^{\prime \prime \prime}\right)$ suggested that the cinnamoyl group was located at C-2" of the sugar moiety (Figure 2 and Supporting information).

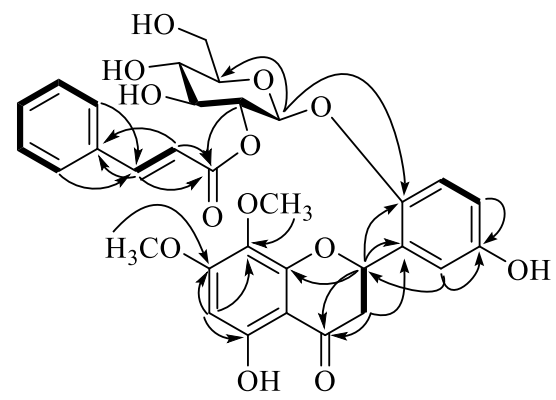

$$
\longrightarrow{ }^{1} \mathrm{H}^{1}{ }^{1} \mathrm{H} \text { COSY }
$$

Figure 2. Important ${ }^{1} \mathrm{H}-{ }^{1} \mathrm{H}-\mathrm{COSY}$ and $\mathrm{HMBC}$ correlations for gymnosporioside (1)

Flavanones that have a $2 S$-configuration can exhibit positive Cotton effects, due to an $\mathrm{n}-\pi^{*}$ transition (approximately $330 \mathrm{~nm}$ ), and negative Cotton effects, due to a $\pi-\pi^{*}$ transition (270-290 $\mathrm{nm}$ ), in the circular dichroism (CD) spectra [17, 18]. In our experiment, the CD curve for compound 1 (Figure 3) exhibited positive Cotton effects at $\Delta \varepsilon_{303}+8.75$ and negative Cotton effects at $\Delta \varepsilon_{77}-16.55$, which established the $2 S$-configuration $[17,18]$. Based on these findings, compound 1 was determined to be (2S)-5,5'-dihydroxy-7,8-dimethoxyflavanone-2'- $O$ - $\beta$-D-(2"'-O-cinnamoyl)glucopyranoside, named gymnosporioside.

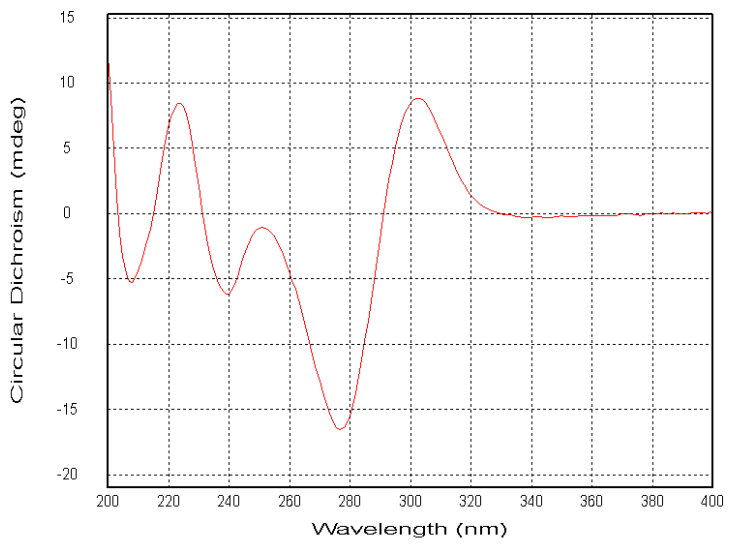

Figure 3. Experimental ECD spectrum of compound 1 in $\mathrm{MeOH}$

The known compounds were identified as prunin (2) [19], acteoside (3) [20], and isoacteoside (4) [21], by comparing their NMR data (Supporting information) from this study with those reported in the literatures.

To test the cytotoxic effects of compounds 1-4 in RAW 264.7 cells, we evaluated their cytotoxicity, in the presence and/or absence of lipopolysaccharides (LPS), by using the 3-(4,5dimethylthiazol-2-yl)-2,5-diphenyltetrazolium bromide (MTT) assay. These compounds showed no significant cytotoxic effects on cell viability, even at doses as high as $50 \mu \mathrm{M}$, after $24 \mathrm{~h}$ incubations, regardless of the presence or absence of LPS (data not shown). To examine the nitric oxide (NO) production inhibitory activity of these compounds, RAW 264.7 cells were treated with isolated compounds, at several concentrations $(1,3,10$ and $30 \mu \mathrm{M})$, and the level of NO production was determined by assessing nitrite quantities in the cell culture supernatants. The results demonstrated that compounds 3 and $\mathbf{4}$ effectively inhibited NO production, with $\mathrm{IC}_{50}$ values of $17.8 \pm 0.4$ and $19.3 \pm$ $0.3 \mu \mathrm{M}$, respectively (Table 1). However, compounds $\mathbf{1}$ and $\mathbf{2}$ were inactive $\left(\mathrm{IC}_{50}\right.$ values $\left.>30 \mu \mathrm{M}\right)$. In 
this assay, celastrol, a natural secondary metabolite, was used as a positive inhibitor. Celastrol expressively inhibited LPS-induced NO production with an $\mathrm{IC}_{50}$ value of $1.0 \pm 0.1 \mu \mathrm{M}[9,10,22]$.

Table 1. NO production inhibitory activity of isolated compounds $\mathbf{1 - 4}$

\begin{tabular}{cc}
\hline Compound & $\mathrm{IC}_{50}$ value $(\mu \mathrm{M})^{a}$ \\
\hline $\mathbf{1}$ & $>30$ \\
$\mathbf{3}$ & $>30$ \\
$\mathbf{4}$ & $17.8 \pm 0.4$ \\
Celastrol $^{b}$ & $19.3 \pm 0.3$ \\
${ }^{a}$ The inhibitory effects are represented as the molar concentration $(\mu \mathrm{M})$ giving $50 \%$ \\
inhibition (IC50) relative to the vehicle control. These data represent the average values of \\
three repeated experiments (mean \pm S.D). \\
${ }^{b}$ Positive control.
\end{tabular}

\section{Acknowledgement}

This research is funded by Vietnam National Foundation for Science and Technology Development (NAFOSTED) under grant number 104.01-2016.21. We thank Dr. Nguyen Quoc Binh (Vietnam National Museum of Nature) for identification of plant species and the Center for Applied Spectroscopy, Institute of Chemistry (VAST) for spectroscopic measurement.

\section{Supporting Information}

Supporting Information accompanies this paper on http://www.acgpubs.org/journal/recordsof-natural-products

\section{ORCID}

Dang Thach Tran: 0000-0002-3721-8922

Phi Hung Nguyen: 0000-0002-6678-4253

Manh Hung Tran: 0000-0003-3061-7952

Phuong Dai Nguyen Nguyen: 0000-0003-2522-9488

Truong Nhan Ngu: 0000-0002-4387-685X

Thi Huyen Thoa Pham: 0000-0002-6449-309X

Dao Cuong To: 0000-0003-4497-7289

\section{References}

[1] D. Bhavita, B. Lakshmi and Z. Maitreyi (2017). An overview on ethanomedicinal plant Gymnosporia montana of Celestraceae family, J. Med. Plants Stud. 5, 86-89.

[2] N. T. T. Ha, T. B. Ngan, P. V. Cuong, D. T. M. Huong, N. V. Hung and M. Litaudon (2014). Chemical constituents from the stems of Gymnosporia stylosa (Celastraceae), Vietnam J. Chem. 52, 2014-2018.

[3] A. Nishat and C. Divya (2019). Antioxidant studies on methanol and aqueous extracts of Gymnosporia montana plant, Int. J. Pharm. Pharm. Sci. 11, 65-70.

[4] D. Bhavita, B. Lakshmi, J. Khushboo and Z. Maitreyi (2018). Development and standardization of novel herbal formula for the management of liver disease, Int. J. Pharm. Pharm. Sci. Rev. Res. 50, 77-82.

[5] D. Bhavita, B. Lakshmi and Z. Maitreyi (2018). Cytotoxicity activity of Gymnosporia montana on Hepatocellular Carcinoma cell line (HEP G2), Int. J. Pharm. Pharm. Sci. Rev. Res. 49, 111-113.

[6] K. Aloka, N. Devashan, B. Ponnusamy, D. Karel, N. Jaroslav and V. S. Johannes (2018). Phenolic and flavonoid production and antimicrobial activity of Gymnosporia buxifolia (L.) Szyszyl cell Cultures, Plant Growth Regul. 86, 333-338. 
[7] C. O. Ochieng, S. A. Opiyo, E. W. Mureka and I. O. Ishola (2017). Cyclooxygenase inhibitory compounds from Gymnosporia heterophylla aerial parts, Fitoterapia 119, 168-174.

[8] K. S. Ahn, E. J. Noh, H. L. Zhao, S. H. Jung, S. S. Kang and Y. S. Kim (2005). Inhibition of inducible nitric oxide synthase and cyclooxygenase II by Platycodon grandiflorum saponins via suppression of nuclear factor-kappaB activation in RAW 264.7 cells, Life Sci. 76, 2315-2328.

[9] T. D. Cuong, T. M. Hung, M. Na, D. T. Ha, J. C. Kim, D. Lee, S. Ryoo, J. H. Lee, J. S. Choi and B. S. Min (2011). Inhibitory effect on NO production of phenolic compounds from Myristica fragrans, Bioor. Med. Chem. Lett. 21, 6884-6887.

[10] P. Gürbüz, S.D. Dogan, G. N. Celik, H. Bekci, A. Cumaoglu, M. G. Gunduz and M.Y. Paksoy (2019). Bioactivity-guided isolation of anti-inflammatory principles from Cistus parviflorus Lam., Rec. Nat. Prod. 13(3), 226-235.

[11] P. K. Agrawal (1989). Carbon-13 NMR of Flavonoids, Elsevier publishing, New York.

[12] M. Furukawa, H. Suzuki, M. Makino, S. Ogawa, T. Iida and Y. Fujimoto (2011). Study on the constituents of Lagochilus leiacanthus (Labiatae), Chem. Pharm. Bull. 59, 1535-1540.

[13] B. S. Min, M. K. Na, S. R. Oh, K. S. Ahn, G. S. Jeong, G. Li, S. K. Lee, H. Joung and H. K. Lee (2004). New Furofuran and Butyrolactone Lignans with Antioxidant Activity from the Stem Bark of Styrax japonica, J. Nat. Prod. 67, 1980-1984.

[14] P. T. Thuong, H. J. Kang, M. Na, W. Jin, U. J. Youn, Y. H. Seong, K. S. Song, B. S. Min and K. Bae (2007). Anti-oxidant constituents from Sedum takesimense, Phytochemistry 68, 2432-2438.

[15] B. S. Min, T. D. Cuong, J. S. Lee, B. S. Shin, M. H. Woo and T.M. Hung (2010). Cholinesterase inhibitors from Cleistocalyx operculatus buds, Arch. Pharm. Res. 33, 1665-1670.

[16] B. S. Min, T. D. Cuong, M. H. Woo and T.M. Hung (2010). Flavonoids from Cleistocalyx operculatus and their cytotoxic activity, Bull. Korean Chem. Soc. 31, 2392-2394.

[17] W. Gaffield (1970). Circular dichroism, optical rotatory dispersion and absolute configuration of flavanones, 3-hydroxyflavanones and their glycosides: Determination of aglycone chirality in flavanone glycosides, Tetrahedron 26, 4093-4108.

[18] Y. Miyaichi, Y. Imoto, T. Tomimori and T. Namba (1988). Studies on the Nepalese Crude Drugs. IX.: On the Flavonoid Constituents of the Root of Scutellaria scandens BUCH.-HAM. ex D. DON, Chem. Pharm. Bull. 36, 2371-2376.

[19] W. Rahman, K. Ishratullah, H. Wagner, O. Seligmann, V. Mohan Chari and B. G. Österdahl (1978). Prunin-6"-O-p-coumarate, a new acylated flavanone glycoside from Anacardium occidentale, Phytochemistry 17, 1064-1065.

[20] Elkattan, A. Gohar, M. Amer, Z.M. Naeem, A. Ashour and K. Shimizu (2020). Melanin synthesis Inhibitors from Olea europeae, Rec. Nat.Prod. 14(2), 139-143.

[21] T. Kanchanapoom, R. Kasai and K. Yamasaki (2002). Phenolic glycosides from Markhamia stipulate, Phytochemistry 59, 557-563.

[22] T. D. Cuong, T. M. Hung, B. S. Min, B. S. Shin and M. H. Woo (2012). Compounds from the heartwood of Caesalpinia sappan and their anti-inflammatory activity, Bioorg.. Med. Chem. Lett. 22, 7436-7439.

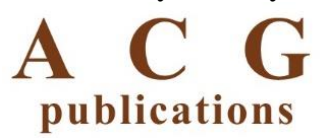

(C) 2020 ACG Publications 